\title{
Outbreak of invasive meningococcal disease in Goleniów County, north-west Poland, March 2009
}

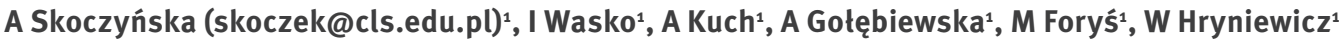

1. National Reference Centre for Bacterial Meningitis, National Medicines Institute, Warsaw, Poland

Citation style for this article:

Skoczyńska A, Wasko I, Kuch A, Gołebiewska A, Foryś M, Hryniewicz W. Outbreak of invasive meningococcal disease in Goleniów County, north-west Poland, March 2009. Euro Surveill. 2010;15(34):pii=19646. Available online: http://www.eurosurveillance.org/ViewArticle.aspx?Articleld=19646

Article published on 26 August 2010

In March 2009, six cases of invasive meningococcal disease (IMD) were reported in two communes of Goleniów County in north-west Poland. The people affected were aged from seven to 25 years. The overall incidence rate in the county was eight per 100,000 population. All the patients recovered fully. No epidemiological links were established between the cases. All were infected with Neisseria meningitidis serogroup C, sequence type (ST) 11 and analysis of isolate DNA restriction fragment length polymorphism showed indistinguishable pulsed-field gel electrophoresis (PFGE) patterns. Sequencing of porA and fet $A$ genes revealed that all isolates had PorA variant $P_{1.5,2}$ and FetA variant F3-3. Based on epidemiological and microbiological data, the Polish Working Party on Meningococcal Infections took the decision to compulsorily vaccinate populations at highest risk in the region - primarily people aged from 6 to 19 years.

\section{Introduction}

Neisseria meningitidis, which in most instances asymptomatically colonises the human nasopharynx, may also cause rapid-onset septicaemia or meningitis conditions that are referred to as invasive meningococcal disease (IMD). Although cases of IMD usually appear only sporadically, they may also emerge in clusters, outbreaks and large epidemics [1]. In Poland, IMD is a notifiable disease. Every suspected case has to be reported by physicians to the local Sanitary Inspectorate within 24 hours of hospital admission. All local Sanitary Inspectorates are then required to report the cases to the National Institute of Public Health National Institute of Hygiene, which collates the information from the whole country. In addition to this mandatory notification, there is a laboratory-based surveillance system run by the National Reference Centre for Bacterial Meningitis. This centre collects all bacterial isolates from hospital laboratories as well as clinical materials (to be used if bacterial culture fails) from people with community-acquired invasive bacterial infections, including IMD. This activity is crucial for monitoring national trends in IMD and for detecting clusters or outbreaks of the disease, and thus enabling correct medical and epidemiological management.
Until 2009, N. meningitidis had been the most common laboratory-confirmed aetiological agent of community-acquired invasive bacterial infections in Poland (unpublished data). The incidence rate of IMD in the country is around one per 100,000 population [2-4]. As in some other countries (for example, Austria, Bulgaria, Denmark, Finland, Latvia and Norway), there is no mass vaccination against serogroup $C$ meningococci in Poland [5].

This report describes an outbreak of IMD $(n=6)$ in Goleniów County in the West Pomeranian region of Poland, close to the Polish-German border, in March 2009. It affected two communes, Goleniów and Przybiernów, with 33,000 and 5,180 habitants, respectively. The international Szczecin-Goleniów Airport is close to Goleniów, the capital of Goleniów County. West Pomerania has been severely affected by IMD in the past: from April 2003 to March 2004 the reported case-fatality rate of IMD caused by various meningococcal strains (of serogroups B, C and W-135) was very high: $43 \%$ (nine of 21 cases) [6]. More than half of the patients $(n=13)$ developed meningococcal septicaemia, of whom nine died. Such a high number of cases with septicaemia accelerated the decision of Polish authorities to change the notification system. Since $\mathbf{2 0 0 4}$, it has been obligatory to report all IMD cases, not only those with meningitis. Since then, the number of reported IMD cases in Poland started to increase. Until 2006, there were mostly sporadic cases, though there were some family clusters. However, in 2006 and 2007, at least five outbreaks of IMD, with high casefatality rates, were notified in various parts of the country $[7,8]$. At the beginning of 2008 , there was one outbreak in the Świętokrzyskie region (in the southeast) and then until the Goleniów County outbreak in March 2009, only sporadic cases had been reported in the country (unpublished data).

\section{Methods}

Case definition

In Poland, the definition of confirmed IMD case is similar to the European Union case definition of confirmed meningococcal case [9], encompassing patients meeting the following inclusion criteria: 
- $\quad$ having symptoms of invasive bacterial disease (at least one of the following: fever, meningeal signs, petechial rash, septic shock or septic arthritis); and

- $\quad$. meningitidis isolated from a normally sterile site; or

- $\quad$ meningococcal DNA identified by polymerase chain reaction $(P C R)$ in material from a normally sterile site; or

- Gram-negative diplococci detected in cerebrospinal fluid.

The Polish definition of confirmed IMD case does not include detection of $N$. meningitidis antigen in cerebrospinal fluid.

\section{N. meningitidis isolation and characterisation}

$N$. meningitidis was isolated from the six IMD cases in local hospital laboratories and identified according to their standard procedures. For subsequent characterisation, isolates were sent to the National Reference Centre for Bacterial Meningitis in Warsaw. Serogroups were determined by slide agglutination tests using commercial antisera (Remel). Serotypes and subtypes were evaluated by whole-cell enzyme-linked immunosorbent assay (ELISA) using monoclonal antibodies (from the National Institute for Biological Standards and Control, United Kingdom) [10]. Minimal inhibitory concentrations were assessed by the Etest method (bioMerieux).

The relatedness of isolates was determined by restriction fragment length polymorphism (RFLP) analysis of genomic DNA in pulsed-field gel electrophoresis (PFGE), using Spel restriction enzyme for DNA digestion. The meningococci were also characterised by multilocus sequence typing and DNA sequencing of the porA and fet $A$ genes, which encode outer membrane proteins $[11,12]$. Sequence types (ST) and PorA and FetA types were determined through the meningococcal typing website [13].

\section{Results \\ Description of the outbreak}

From 10 to 30 March 2009, there were six cases of IMD in Goleniów County. In Goleniów commune, there were four cases in the town of Goleniow and one in the village of Załom; in Przybiernów commune, there was one case in the village of Łoźnica. The age of the cases ranged from 7 to 25 years (Table): in the age group six to 19 years, the incidence rate in the two communes was 78 per 100,000 population. The overall incidence rate in the county was eight per 100,000 population, whereas the annual national incidence of the disease is around one per 100,000 population [2-4]. In Goleniów and Przybiernów communes, the overall incidence rates were 15 per 100,000 population and 19 per 100,000 population, respectively.

Half of the cases were female (Table). No epidemiological links were established between the patients and, to our knowledge, none of the cases were imported.
Three cases presented with meningococcal sepsis along with meningitis, two with meningococcal sepsis and one with meningitis (Table). All patients except the case with meningitis developed petechial rash. Four patients were admitted to a hospital in Goleniów County, where samples were taken and they received initial therapy with third-generation cephalosporins (ceftriaxone or cefotaxime). They were then transported to three regional hospitals in Szczecin (the capital city of West Pomerania), where the two other patients were admitted directly. All the patients recovered fully.

\section{Control of the outbreak}

Immediately after diagnosis of possible IMD, based on clinical assessment of symptoms, the cases were reported by the hospitals to the local Sanitary Inspectorate, and chemoprophylaxis (with rifampicin, cefotaxime, ciprofloxacin or azithromycin) was given to the cases' close contacts (Table), as recommended by the National Reference Centre for Bacterial Meningitis [14].

Testing at the National Reference Centre showed that all cases were infected with $N$. meningitidis serogroup C, serotype 2 a, serosubtype $\mathrm{P}_{1.5}, \mathbf{2}$ of ST-11. Analysis of restriction fragment length polymorphism showed indistinguishable PFGE patterns. DNA sequencing of the porA and fet $A$ genes revealed that all had PorA variant $P_{1.5,2}$ and FetA variant $F_{3}-3$. All isolates were susceptible to penicillin, cefotaxime, chloramphenicol, ciprofloxacin and rifampicin.

On 20 March 2009 (10 days after the first case developed symptoms), a campaign began, organised by the local health authorities to educate hospital physicians, other health professionals and the general public about IMD. Among others things, it included meetings in kindergartens and schools for children and parents, the posting of relevant publications on local and regional governmental and Sanitary Inspectorate websites, publication of articles and notices in local newspapers, television spots and dissemination of special posters and leaflets.

Ten days later, the country's Working Party on Meningococcal Infections, acting as an advisory body to the Chief Sanitary Inspectorate, reviewed the epidemiological situation and strongly recommended vaccination against meningitis to the Ministry of Health. As incidence was highest in the age group six to 19 years, the Ministry of Health decided to vaccinate people in that age group in Goleniów and Przybiernów communes, as well as children in the same age group from other communes who attended schools in the affected region (approximately 6,500 children). Additionally, police, border guards and airport ground staff up to 24 years old from Goleniów County were vaccinated. Each person received one dose of meningococcal conjugated vaccine against serogroup C. Young adults (aged older than 19 years) in the general population were excluded from compulsory vaccination, even though the oldest patient was 25 years old. This was primarily due to 
organisational difficulties in reaching this population for vaccination. In addition, as the oldest case in the outbreak had Hodgkin disease, it was thought that this patient may have been immunocompromised, due to chemo- and radiotherapy.

Vaccination began on 9 April 2009 and was scheduled to end on 30 April. However, as some children could not be vaccinated during this time, due to temporary contraindications, and to increase coverage, further vaccination took place from 4 to 29 May 2009. By the end of May, almost $82 \%(n=5,256)$ of the target population had been vaccinated. This value was calculated using the number of residents of Goleniów and Przybiernów communes, the number of children aged six to 19 years from other communes who attended schools in the affected area and vaccine uptake. Any children who missed the vaccination in April and May were then scheduled for vaccination from 15 to 19 June 2009.

\section{TABLE}

Patient data and typing results of Neisseria meningitidis isolates responsible for invasive meningococcal disease, Goleniów County, Poland, March 2009 (n=6)

\begin{tabular}{|c|c|c|c|c|c|c|c|c|c|c|}
\hline $\begin{array}{l}\text { Case } \\
\text { number }\end{array}$ & $\begin{array}{c}\text { Age } \\
\text { (years) }\end{array}$ & Sex & $\begin{array}{l}\text { Date of } \\
\text { symptom } \\
\text { onset } \\
(2009)\end{array}$ & Diagnosis & Sample & Serogroup & $\begin{array}{c}\text { Multilocus } \\
\text { sequence } \\
\text { type }\end{array}$ & $\begin{array}{c}\text { PorA } \\
\text { variant }\end{array}$ & $\begin{array}{c}\text { FetA } \\
\text { variant }\end{array}$ & $\begin{array}{c}\text { Number of } \\
\text { contacts } \\
\text { who received } \\
\text { chemoprophylaxis }\end{array}$ \\
\hline 1 & 7 & $M$ & $10 \mathrm{Mar}$ & Sepsis & Blood & C & 11 & $P_{1.5,2}$ & $F_{3}-3$ & 7 \\
\hline 2 & 17 & $M$ & $13 \mathrm{Mar}$ & Meningitis & CSF & $C$ & 11 & $P_{1.5,2}$ & $F_{3}-3$ & 37 \\
\hline 3 & 17 & $\mathrm{~F}$ & 17 Mar & $\begin{array}{l}\text { Meningitis } \\
\text { and sepsis }\end{array}$ & Blood & C & 11 & $P_{1.5,2}$ & $F_{3}-3$ & 3 \\
\hline 4 & 13 & $\mathrm{~F}$ & 17 Mar & $\begin{array}{l}\text { Meningitis } \\
\text { and sepsis }\end{array}$ & $\begin{array}{l}\text { CSF and } \\
\text { blood }\end{array}$ & C & 11 & $P_{1.5,2}$ & $F_{3}-3$ & 6 \\
\hline 5 & 25 & M & 24 Mar & $\begin{array}{l}\text { Meningitis } \\
\text { and sepsis }\end{array}$ & Blood & C & 11 & $P_{1.5,2}$ & $F_{3}-3$ & 3 \\
\hline 6 & 15 & $\mathrm{~F}$ & 30 Mar & Sepsis & Blood & $\mathrm{C}$ & 11 & $P_{1.5,2}$ & $F_{3}-3$ & 14 \\
\hline
\end{tabular}

CSF: cerebrospinal fluid; F: female; M: male.

\section{FIGURE}

Number and percentage of laboratory-confirmed invasive meningococcal disease cases, by mode of identification, Poland, $2006-2009(n=1,106)^{\mathrm{a}}$

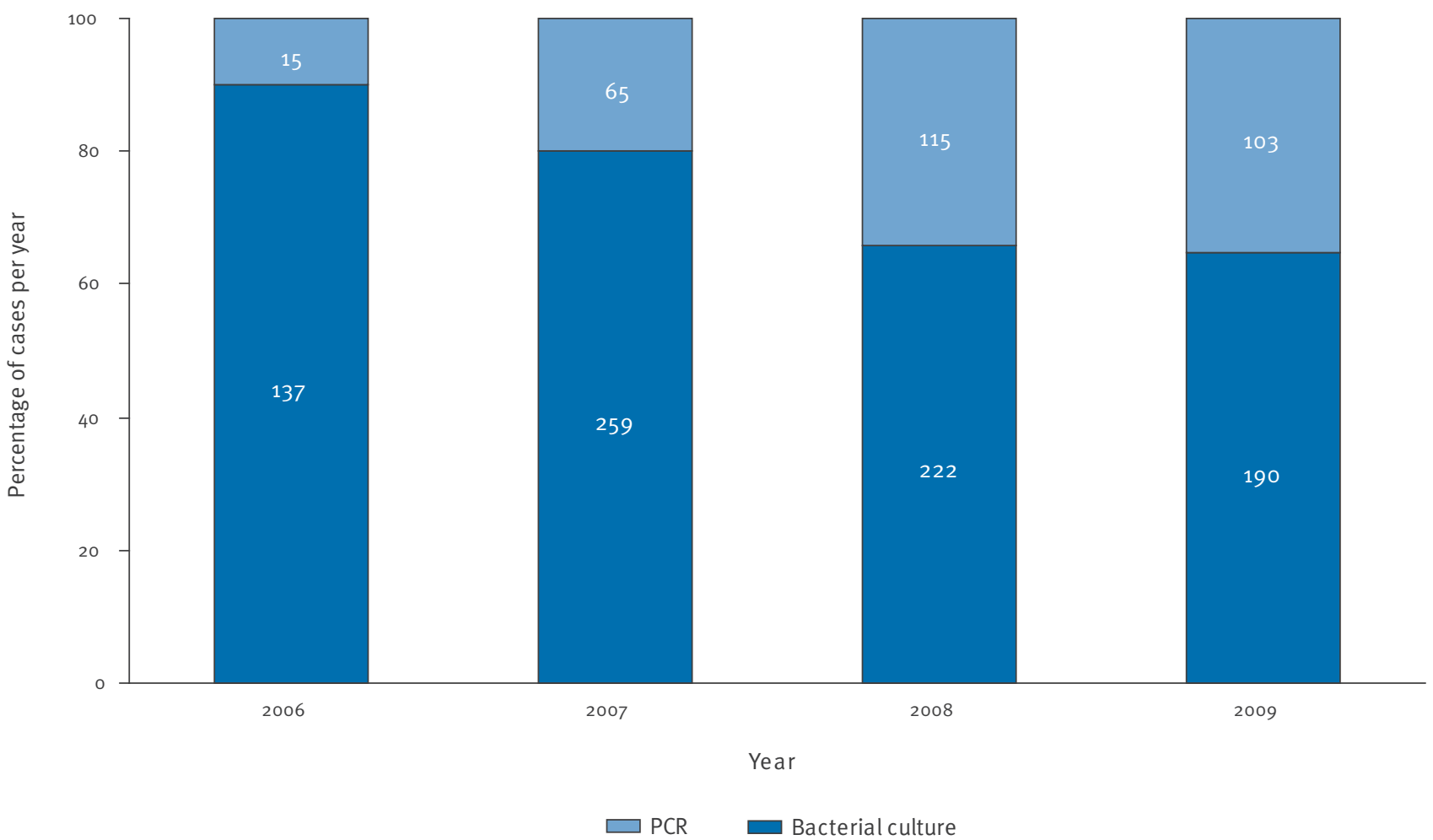

a Tested by the National Reference Centre for Bacterial Meningitis. 


\section{Discussion}

Goleniów County, where the outbreak described took place, is situated in the West Pomeranian region, which had previously experienced a very high case-fatality rate for IMD [6]. At that time, in 2004, the Working Party on Meningococcal Infections had not yet been established, but the situation was closely observed by regional and Chief Sanitary Inspectorates. Despite widely disseminated information and regional alerts directed at health professionals, only 13 of 21 IMD cases were confirmed by bacterial culture and only 12 isolates were available for further testing at the National Reference Centre at that time (in 2004). There was also poor culture confirmation of IMD in 2006-2007, when at least five outbreaks of IMD, also associated with a high case-fatality rate, were notified in different parts of Poland $[7,8]$. Generally, the number of blood samples sent for microbiological evaluation in Poland is still low, due to limited financial means. According to data collected by the European Antibiotic Resistance Surveillance System (EARSS), the frequency of bacterial culture from blood in Poland is several times lower than that in some other European countries such as the Netherlands, Spain, Sweden and the United Kingdom [15].

As a result, the National Reference Centre for Bacterial Meningitis decided in 2008 to enhance laboratorybased surveillance of invasive bacterial infections, including IMD, by building a voluntary network (called BINet) for monitoring community-acquired invasive bacterial infections, of up to 150 Polish hospitals and microbiological laboratories. For all laboratories in the network, transport of isolates from the hospitals to the National Reference Centre and the tests carried out there are provided free of charge. Two years after BINet started, the education of clinicians and microbiologists and the increase in bacteriological testing have substantially improved the identification of community-acquired invasive bacterial infections in Poland, especially those caused by $N$. meningitidis (Figure) and Streptococcus pneumoniae $[8,16]$. This enhanced monitoring and the earlier experience gained in the West Pomeranian region led to better handling of microbiological specimens and resulted in full characterisation of all isolates from the Goleniów County outbreak. Of the three hospitals that sent isolates to the National Reference Centre, one has not been involved in BINet, but cooperates closely with the National Reference Centre. Due to rapid diagnosis and correct management, all the patients fully recovered, despite having infections caused by hypervirulent ST-11 meningococci, generally associated with a high case-fatality rate $[17,18]$. This may illustrate that education results in higher awareness of healthcare workers and the general population, enabling immediate reaction when there is probable meningococcal infection.

All cases $(n=34)$ in all the five reported outbreaks in Poland in 2006 and 2007, as well as 56 sporadic cases notified during this time, were infected with an ST-11 meningococcus that had a PorA variant (P1.5-1,10-1) differing from the PorA of ST-11 isolates identified in Poland from 1997 to $2005\left(\mathrm{P}_{1.5,2)}\right.$ [7]. The meningococci responsible for the Goleniów County outbreak had the same PorA variant as that of ST-11 meningococci isolated before $2006\left(\mathrm{P}_{1.5}, 2\right)$. However, the Goleniów County isolates had an FetA variant (F3-3) that differed from all sequenced ST-11 isolates responsible for IMD cases before 2009 in Poland (generally F3-6, only two isolates had F3-9) (unpublished data). It has been suggested that even very small alterations in antigenic characteristics, which can be the result of a point mutation, may result in an increase in the number of IMD cases in particular areas $[19,20]$. Such antigenic changes were observed in the PorA and FetA proteins of ST-11 isolates before the 2006 and 2007 outbreaks in Poland and in the 2009 Goleniów County outbreak described here, which may partially explain the occurrence of these outbreaks.

In spite of increases in the number of IMD sporadic cases and outbreaks caused by serogroup C meningococci over the last few years, Poland still does not carry out mass vaccination against this serogroup. The national health budget is very limited, evidenced by the fact that Poland only introduced mass vaccination against Haemophilus influenzae type b (Hib) in 2007. Consequently, when meningococcal outbreaks occur, the situation is thoroughly analysed by the Working Party on Meningococcal Infections, which may recommend obligatory vaccination to the Ministry of Health when there is an epidemiological threat.

Despite limited resources, more and more parents and local authorities are deciding to vaccinate their children and their citizens (in certain age groups) respectively against serogroup C meningococci. In 2008, more than 110,000 doses of vaccine against meningococci $C$ were sold in Poland [21]. Vaccination initiatives should be considered across the country, including in Goleniów County, where at the end of August 2009, a non-vaccinated two-year-old boy developed fatal septicaemia caused by meningococci of serogroup C, ST-11 (with the same variants of PorA and FetA as the Goleniów County outbreak isolates) (unpublished data).

\section{Acknowledgements}

We thank all physicians and microbiologists contributing isolates and data.

References

1. Stephens DS, Greenwood B, Brandtzaeg P. Epidemic meningitis, meningococcaemia, and Neisseria meningitidis. Lancet. 2007;369(9580):2196-210.

2. National Institute of Hygiene-National Institute of Public Health and Chief Sanitary Inspectorate. [Infectious diseases and poisoning in Poland in 2007]. Warsaw 2008. Polish. [Accessed 22 Jul 2010]. Available from: http://www.pzh.gov.pl/oldpage/ epimeld/2007/Ch_2007.pdf

3. National Institute of Hygiene-National Institute of Public Health and Chief Sanitary Inspectorate. [Infectious diseases and poisoning in Poland in 2008]. Warsaw 2009. Polish. [Accessed 21 Jul 2010]. Available from: http://www.pzh.gov.pl/oldpage/ epimeld/2008/Ch_2008.pdf 
4. National Institute of Hygiene-National Institute of Public Health and Chief Sanitary Inspectorate. Zachorowania na wybrane choroby zakaźne w Polsce od 1 stycznia do 31 grudnia 2009 r.oraz w porównywalnym okresie 2008 r. [Morbidity of selected infectious diseases in Poland from 1 January until 31 December 2009 and in compared period in 2008]. Polish. [Accessed 22 Jul 2010]. Available from: http://www.pzh.gov.pl/oldpage/ epimeld/2009/INF_09_12B.pdf

5. European surveillance network for vaccine-preventable diseases (EUVAC.NET). Meningococcal vaccination (MenC) overview in European countries. [Accessed 21 Jul 2010]. Available from: http://www.euvac.net/graphics/euvac/ vaccination/menc.html

6. Skoczyńska A, Kadłubowski M, Knap J, Szulc M, Janusz-Jurczyk M, Hryniewicz W. Invasive meningococcal disease associated with a very high case fatality rate in the North-West of Poland. FEMS Immunol Med Microbiol. 2006;46(2):230-5.

7. Kadlubowski M, Wasko I, Klarowicz A, Hryniewicz W. Invasive meningococcal disease at a military base in Warsaw, January 2007. Euro Surveill. 2007;12(9). pii=3147. Available from: http://www.eurosurveillance.org/ViewArticle. aspx?Articleld $=3147$

8. Skoczyńska A, Hryniewicz W. Epidemiologia inwazyjnych zakazeń meningokokowych w Polsce [Epidemiology of invasive meningococcal infections in Poland]. Medycyna po Dyplomie 2009; Supl. 01/09:1-3. Polish.

9. European Commission. Commission Decision of $28 / \mathrm{IV} / 2008$ amending Decision 2002/253/EC laying down case definitions for reporting communicable diseases to the Community network under Decision No 2119/98/EC of the European Parliament and of the Council. Brussels; 28 Apr 2008. Available from: http://ec.europa.eu/health/ph_threats/com/ docs/1589_2008_en.pdf

10. Abdillahi H, Poolman JT. Whole-cell ELISA for typing Neisseria meningitidis with monoclonal antibodies. FEMS Microbiol Lett. 1987;48(3):367-71.

11. Maiden MC, Bygraves JA, Feil E, Morelli G, Russell JE, Urwin $\mathrm{R}$, et al. Multilocus sequence typing: a portable approach to the identification of clones within populations of pathogenic microorganisms. Proc Natl Acad Sci U S A. 1998;95(6):3140-5.

12. Jolley KA, Brehony C, Maiden MC. Molecular typing of meningococci: recommendations for target choice and nomenclature. FEMS Microbiol Rev. 2007(1):31:89-96.

13. Neisseria.org. Meningococcal typing. Oxford: Neisseria.org (University of Oxford). [Accessed 21 Jul 2010]. Available from: http://neisseria.org/nm/typing/

14. National Reference Centre for Bacterial Meningitis. Rekomendacje dotyczące profilaktyki inwazyjnej choroby meningokokowej. [Recommendations on prophylaxis of invasive meningococcal disease]. 1 Jun 2009. Polish. Available from: http://www.koroun.edu.pl/pdf/rekomendacjePRO.pdf

15. European Antibiotic Resistance Surveillance System (EARSS). EARSS annual reports 2007. Bilthoven: National Institute for Public Health and the Environment (RIVM); Oct 2008. Available from: http://www.rivm.nl/earss/Images/EARSS\%202007_ FINAL_tcm61-55933.pdf

16. Skoczyńska A, Hryniewicz W. Monitorowanie bakteriologiczne warunkiem skutecznej terapii i profilaktyki pozaszpitalnych bakteryjnych zakażeń inwazyjnych. [Necessity of bacteriologic monitoring for efficacious therapy and prophylaxis of community-acquired invasive bacterial infections]. Pediatria po Dyplomie 2009, wyd. specj. IV 2009:7-14. Polish.

17. Trotter CL, Fox AJ, Ramsay ME, Sadler F, Gray SJ, Mallard $R$, et al. Fatal outcome from meningococcal disease--an association with meningococcal phenotype but not with reduced susceptibility to benzylpenicillin. J Med Microbiol. 2002;51(10):855-60.

18. Zarantonelli ML, Lancellotti M, Deghmane AE, Giorgini D, Hong E, Ruckly C, et al. Hyperinvasive genotypes of Neisseria meningitidis in France. Clin Microbiol Infect. 2008;14 (5):467-72.

19. Harrison LH, Jolley KA, Shutt KA, Marsh JW, O’Leary M, Sanza LT, et al. Antigenic shift and increased incidence of meningococcal disease. J Infect Dis. 2006;193(9):1266-74.

20. McGuinness BT, Clarke IN, Lambden PR, Barlow AK, Poolman JT, Jones DM, et al. Point mutation in meningococcal por A gene associated with increased endemic disease. Lancet. 1991;337(8740):514-7.

21. National Institute of Hygiene-National Institute of Public Health and Chief Sanitary Inspectorate. Szczepienia ochronne w Polsce w 2008 roku. [Vaccinations in Poland in 2008]. Warsaw 2009. Polish. Available from: http://www.pzh.gov.pl/oldpage/ epimeld/2008/Sz_2008.pdf 